\title{
The visual principle and the correlation between teaching of the Catholic religion and art education in Polish school
}

\begin{abstract}
Contemporary culture - as already noted - is becoming more and more visual. Contemporary catechesis, referring to its rich, centuries-long experience, should also use different types of images. The first part of this article presents the visual principle as one of basic educating principles, and the second part presents the correlation between the teaching of Catholic religion, and art education in Polish schools. One specific example of using religious painting are in textbooks.

Masterpieces of painting, created during centuries and expressing particular desires of their creators, still remain an important inspiration, among others, to the religious search. Faith, though strongly anchored in words, needs representations, specific references, which allow receiving, understanding, and experiencing it. Paintings give this possibility, and even - taking into consideration the contemporary civilization - impose the necessity to use them, in order to effectively reach the contemporary receiver.

Using images in education is not only the achievement of specific objectives in catechesis, but also gives an opportunity to creatively engage students and shape their aesthetic sensibility. Working with the image creates the possibility of discovering the beauty, to see it in reality and "keeping the heart", that is the enrichment of the beauty of one's humanity.
\end{abstract}

\section{Keywords}

Catechesis - the visual principle - correlation - picture - religious painting - teaching of the Catholic religion - art education - textbooks.

Opinions saying that, nowadays, people practise more showing and looking, instead of reading and writing, are very common. A picture becomes the main means of interpersonal communication. The picture, being in the form of photography, drawing or symbol and various motion pictures, affects current consumers in a very suggestive way. An average human being gets in touch 
with thousands of adverts which attract consumers through the means of a "screaming" picture rather than by the means of a text.

The selection of so many pictures which "attract" consumers' consciousness is more and more often being made at the stage of pre-consciousness. Many people reject explanations which are not accompanied by pictures or which can be easily interpreted and evoke positive feelings. Such picture selection is often subconscious and blocks many valuable pictures whilst many bad, negatively affecting pictures are remembered.

It seems that current education has an important and difficult task to handle. It is a task of teaching persons to observe and to interpret reality which surrounds them through accepting valuable pictures and rejecting negative pictures.

Various pictures affect a human's life to a great extent. They are an important part of interpersonal communication. The human being often thinks, speaks and desires by the means of using various pictures. People express themselves, their feelings by the means of transforming them into pictures. Current mass media (internet, television, magazines, posters) take advantage of this human's ability in a professional way (also in the negative meaning). However one can also note certain "picture illiteracy". Particular pictures are interpreted by many people in a superficial way. There is no shift from perception to observation and finally to thinking. The whole interpretation is restricted to fast browsing of pictures. The current didactics and also catechetics take this fact into account. The picture becomes a medium of certain values.

The first part of this article will present the visual principle as one of basic educating principles, and the second part presents the correlation between the teaching of Catholic religion, and art education in Polish schools.

\section{The visual principle in didactics and catechetics}

Images speak louder than words. However, words are necessary to express what images are not able to reflect. Considering different aspects of the influence of words and images, first of all it is worth remembering that both do not have to compete, rather, they may and should complement each other, thus giving the person the possibility to express and discover complex realities in a deeper way. Human perception is based on the senses, and their versatile activation creates an opportunity not only to better remember and understand contents being passed on, but also to experience them deeply and interiorise them effectively. 
The visual principle is the most noted teaching principle in didactics ${ }^{1}$. Commonly, the process of getting to know reality was interchanged with sense perception. However, it was too narrow a conception of the visual. Perception (sometimes only spontaneous) should be followed by conscious observation and evaluation, which is a result of questions put before. The teacher using the visual principle has to organize teaching based on observation, thinking and practice. The visual teaching cannot be put into practice until all these elements are used:

\section{perception $\rightarrow$ observation $\rightarrow$ thinking $\rightarrow$ acting}

In order to use the visual principle correctly, "showing" a picture is not enough. It is necessary to enable pupils to observe, which should make thinking easier, and should encourage pupils to act ${ }^{2}$. Such an organization of pupils' work enables more participation of pupils and develops their creativity. The teacher can also educationally work better with pupils.

A picture is a certain unity of comprehension and form. The picture should be intelligible and interesting, even without need for comment. On the other hand, an illustration is always accompanied by a text (illustrates something). Pictures and illustrations which are used in catechesis should be big enough for everyone to be able to see them, they should not contain too many details, they should be accordant with historical truth, pleasant and expressive.

The visual principle is based on active and creative shifting from concrete to abstract and vice versa. In catechesis such a shift is very difficult. It is necessary to shift from concrete pictures (from showing) to faith, which is based on abstract truths (truths not related to this reality, transcendent truths) and further more: to shift from this faith to life, to acting ${ }^{3}$.

The only pictorial representation of religious truths brings about many problems. In Prof. W. Kubik's opinion: "It is necessary to discard narrow understanding and the use of the visual principle, when teaching about the Divine persons: God the Father, the Holy Spirit, angels etc. by the means of

1 See J. A. Komeński, Wielka dydaktyka, Wrocław 1956, p. 161-199; Cz. Kupisiewicz, Podstawy dydaktyki ogólnej, Warszawa $1994^{10}$, p. 115-118, W. Okoń, Wprowadzenie do dydaktyki ogólnej, Warszawa 199633, p. 175; J. Półturzycki, Dydaktyka dla nauczycieli, Toruń 1997, p. 107-108.

See R. Chałupniak, J. Kostorz, Wybrane zagadnienia z katechetyki, Opole 2002, p. 84-85.

3 See R. Chałupniak, Arcydzieła malarstwa w katechezie, Opole 2013, p. 152-164. 
pictures. The pictures are not convenient "reflections of reality" in such cases. Naturally, it is possible to use works of art but this is recommended only in the catechesis for elder pupils who can separate the intention of an artist who wants to show the beauty, the greatness of God's acting, His goodness, His love, His favour with human being, from the real comprehension of God. The best "picture" of God is a text of the Holy Scripture or testimonies being told by people who experience His acting in their lives. Discovering God's acting in lives of concrete people prepares pupils to discover Him best, also in their lives "4. This reasoning does not solve the problem of visuals in catechesis, particularly the catechesis of younger children. There is still an open question left: How should the teachers present difficult religious truths to children without using concrete pictures?

Catechesis cannot enable direct contact with supernatural reality. However, it is possible to access this reality by the means of the testimony of faith, prayer, participation in liturgy, social-charitable activities, and also pictures and symbols.

Referring to the Catechism of the Catholic Church it should be reminded that the main reason for creating religious paintings, and using them also in catechesis, is the mystery of the embodiment of Jesus Christ. As the Word became flesh, receiving real human nature, the human face of Jesus can be "presented" (cf. CCC 476). This teaching has been confirmed by both former and contemporary directions of the Church. The often repeated sentence "Beauty saves the world" is understood unequivocally in Christianity: the beauty of Jesus Himself is saving in itself.

Many people pass by beauty indifferently, and true works of art often pass unnoticed, remain unknown or not understood. A saturation of all kinds of visual influences may cause specific blindness - many look and do not see, cannot notice the beauty expressed in art. Specific pedagogical influence i.e. education through art assumes that receivers will be more sensitive to this beauty, willing to discover it and delight in it more often. An aesthetic experience is the aim of such education. Moreover, it is a specific way to discover significant questions, human talents, but also constraints. Under the unusual influence of beauty a sensitive person can go further - asking questions about one's life, its sense and value, its passing and eternity. Such experiences, in turn, open one up to faith, invite to deeper thoughts and search. Humanity with its inscrutable mystery is at the centre of both the aesthetic and theological quest.

\footnotetext{
4 W. Kubik, Zarys dydaktyki katechetycznej, Kraków 1990, p. 233.
} 
A characteristic medium to reach a person, but also to discover and experience one's relation to God, may be a particular painting. In the process of creation it became a carrier of a specific message which can be read and, as such, become the inspiration to further thoughts and experiences. Believing artists left works of art that can be treated as a specific testimony of their faith: an invitation to a personal response to God's calling. Artists who wrestled with faith, who did not express it directly in their works, can, in turn, through their paintings provoke crucial questions, struggling for the shape of one's life. Discovering paintings, especially religious ones, always constitutes an interesting area for different experiences, which often lead to the strengthening of faith. Faith that comes by hearing (cf. Rom 10, 17) can develop and strengthen when it is discovered and experienced by seeing.

\section{The correlation between the teaching of the Catholic religion and art education: religious painting in school textbooks}

This next part of text raises the significant issue of the possibility of using esteemed paintings in faith development. Masterpieces of painting, created during centuries and expressing particular desires of their creators, still remain an important inspiration, among others, to the religious search. Faith, though strongly anchored in words, needs representations, specific references, which allow receiving, understanding, and experiencing it. Paintings give this possibility, and even - taking into consideration contemporary civilization - impose the necessity to use them in order to effectively reach the contemporary receiver. All the visualizations of discovered and assimilated realities constitute a challenge for religious educators: how to make the religious transfer more vivid and how to open "the gate of faith" for the people of the $21^{\text {st }}$ century 5 .

\footnotetext{
5 See C. Gärtner, Ästhetisches Lernen. Eine Religionsdidaktik zur Chrystologie in der gymnasialen Oberstufe, Freiburg 2011; M. L. Goecke-Seichab, F. Harz, Christliche Bilder verstehen. Themen, Symbole, Traditionen. Eine Einführung, München 2004; A. Heuser, Glaube lebt von Bildern, in: A. Biesinger, W. Tzscheetzsch (ed.), Das Geheimnis erspüren - zum Glauben anstiften, Freiburg 1989, p. 104-115; R. Hoeps (ed.), Religion aus Malerei? Kunst der Gegenwart als theologische Aufgabe, Paderborn 2005; G. Lange, Bilder zum Glauben, München 2002; M. L. Mazzarello, M. Neghesti, Teaching Religion Through Art in Religious Education in Italian Schools, in: P. Schreiner, F. Kraft, A. Wright (eds.), Good Practice in Religious Education in Europe, Examples and Perspectives of Primary Schools, Berlin 2007, p. 101-114; M. L. Mazzarello, M. F. Tricarico (eds.), Insegnare la religione con l'arte, Torino 2002-2005; G. Meyer, Bilder, Bildung und Christlicher Glaube. Eine Auseinandersetzung mit den Grundlagen einer religionspädagogisch
} 
Up to the $18^{\text {th }}$ century, European painting comprised mostly of religious paintings. The art of that time was closely related to Christianity, and particular works of art passed on the truths of faith, served to ignite the religious imagination, and helped to build a relationship with God. The Church justified the creation of paintings in three ways: as a lesson of faith for the illiterate, as a visual reminder of Christ's life and saints' accomplishments, and as an encouragement for piety. Sacred art had a close connection to Church teaching, and thus, the same topics can be found in paintings originating in different locations and at different times ${ }^{6}$. The didactic, kerygmatic, and pietistic, and liturgical functions of paintings inclined both to create them and to use them in the widely understood work of catechesis i.e. faith education.

In the history of religious painting, a variety of subjects have appeared: biblical, apocryphal, historical, or symbolic. Numerous paintings have maintained their universal meaning, sometimes provoking and sometimes answering the most important questions about life. Though for the last two centuries the influence of religion on the life of societies has significantly weakened, and the majority of the most important Western European works were created without religious references, it does not mean that artists have completely stopped referring to the themes of that kind. Religious issues have gradually become more subtle, coming out, among others, through the specific metaphysicality of representations or taking up the questions about the meaning of life, love, suffering, or death.

In thia article the following division of religious painting is proposed:

- Christian paintings - referring to Christ and the truths of faith passed on in the Church, and, in case of which, a distinct intention of an artist was to present and bequeath the Christian faith,

- sacred paintings meant for religious cult, used in the liturgy, originating from the inspiration of believers in order to present God's beauty and to worship Him,

- religious paintings which refer to a wide range of issues - so called border questions, human dilemmas, or doubts. In this case, religiousness is understood as the specific transcendence of worldly reality, searching for meaning, trying

verantworteten Bildtheorie, Münster - Hamburg - London 2002; G. Schädle, Bilder aus der Kunst im Religionsunterricht. Nachforschungen in Theologie, Kunstgeschichte und Religionspädagogik, Berlin - Münster - Wien - Zürich - London 2008; T. Verdon, Storia dell'arte e catechesi, Bologna 2005.

6 See M. Douglas-Scott, Malarstwo religijne, in: A. Sturgis (ed.), Zrozumieć malarstwo. Najważniejsze tematy w sztuce, Poznań 2006, p. 20. 
to answer questions about the meaning of human life, love and suffering, joys and sorrows?

Such a wide definition of religious painting gives the possibility to find numerous common points between school religious education and art education. A research question is: What religious paintings are used in school textbooks and how are they used?

A very specific example of using painting in religious education is the field of school education. A religion lesson, whose return to Polish schools in 1990 became one of the signs of the regained freedom, for students may be the space to discover their faith - a crucial part of their own worldview. In the school teaching of the Catholic religion, there is a possibility to refer to many different paintings, which form a specific visualization of religious contents passed on. On the other hand, in the case of art education, using various paintings, including those dealing with religious issues, gives the opportunity to present how painting techniques have developed throughout history, and also what subjects were taken up by artists in particular epochs. Those responsible for the shape of catechesis should be aware that religious contents appear within different school subjects.

The word correlation is frequently used in the contemporary didactics and catechetics $^{8}$. The postulate of comprehensive and integral education, though not the newest, both on the level of programming and didactic transmission, encourages to combine various contents, indicate mutual connections between particular knowledge fields. It also, emphasizes how human knowledge, skills, and attitudes, although passed on within different school subjects, are based

7 M. L. Mazzarello, M. F. Tricarico, Arte e catechesi. Note per avviare la riflessione, in: Associazione Italiana Catecheti, D. Marin (ed.), Vie del bello in catechesi. Estetica ed educazione alla fede, Torino 2013, p. 173. Comp. R. Chałupniak, Arcydzieła malarstwa w katechezie, Opole 2013, p. 171.

8 See R. Chałupniak, Sztuka na katechezie. Korelacja lekcji religii z wychowaniem plastycznym, „Katecheta” 47 (2003), nr 7-8, p. 127-133; R. Chałupniak, Doświadczenie estetyczne w wychowaniu religijnym, in: K. Kantowski, W. Lechów (eds.), Ku doświadczeniu wiary. Księga dedykowana Księdzu Profesorowi Andrzejowi Offmańskiemu w 70. rocznicę urodzin i 40. rocznice pracy naukowo-dydaktycznej, Szczecin 2012, p. 145-160; W. Kawecki, Teologia piękna. Poszukiwanie locus theologicus w kulturze wspótczesnej, Poznań 2013; W. Kawecki, Zobaczyć wiarę. Studium obrazu postrzeganego jako komunikacja wiary z perspektywy teologii i kultury mediów, Kraków 2013; A. Kiciński (ed.), Korelacja nauki religii katolickiej z edukacją szkolna, Lublin 2012; K. Klauza, Teokalia. Piękno Boga. Prolegomena do estetyki dogmatycznej, Lublin 2008; J. Królikowski, Sztuka chrześcijańska a wychowanie religijne, in: C. Rogowski (ed.), Leksykon pedagogiki religii, Warszawa 2007, p. 759-763; A. Zellma, Nowa formuła korelacji w edukacji szkolnej i jej realizacja w nauczaniu religii, „Katecheta” 55 (2011), nr 5, p. 5-16. 
on the same attitudes. Such a wide correlation is induced, and even bound, by the curriculum, state ${ }^{9}$, and church documents ${ }^{10}$.

The analysis of textbooks, designed for school religion and art classes, shows to what extent the authors have referred to religious paintings. The year when the books were published played a significant factor. The didactic materials for art education written on the basis of so called the "old" core curriculum of general education i.e. from 2000 to 2008 were analysed first to later compare with the use of religious painting in textbooks according to the "new" core curriculum i.e. after 2008. The books for the Catholic religion were divided similarly: first the study showed how religious paintings were used in the books according to The Core Curriculum of Catechesis from 2001 and next from 2010. In total 33 textbooks for art education were analysed and 98 for the Catholic Religious Education (55 according to the older curriculum and 43 according to the new one $)^{11}$.

In school textbooks various religious paintings have been used. As a rule, the masterpieces of well-known masters have been referred to: Giotto, Leonardo da Vinci, Michelangelo, Caravaggio, Piero della Francesca, Rafael Santi, Peter Paul Rubens, and many others. Some series of textbooks for the Catholic religion lessons referred to the reproductions of lesser-known paintings and sometimes even promoted completely unknown works. From time to time references to the paintings of lesser value and of little aesthetic significance also appeared. Still, they were exceptions, and in general, it can be stated that in textbooks

9 See Minister Edukacji Narodowej, Rozporzadzenie z 15 lutego 1999 r. w sprawie podstawy programowej kształcenia ogólnego. Załacznik nr 1, Dz. U. 1999 nr 14 poz. 129; Minister Edukacji Narodowej i Sportu, Rozporzadzenie z 26 lutego 2002 r. w sprawie podstawy programowej wychowania przedszkolnego oraz kształcenia ogólnego w poszczególnych typach szkót. Załacznik $n r$ 2, Dz. U. 2002 nr 51, poz. 458; Minister Edukacji Narodowej, Rozporzadzenie z 23 grudnia 2008 r. w sprawie podstawy programowej wychowania przedszkolnego oraz kształcenia ogólnego w poszczególnych typach szkót. Załaczniknr 2, Dz. U. 2009 nr 4 poz. 17; Minister Edukacji Narodowej, Rozporzadzenie z 30 maja 2014 r. zmieniajace rozporzadzenie w sprawie podstawy programowej wychowania przedszkolnego oraz kształcenia ogólnego w poszczególnych typach szkót. Załacznik nr 2, Dz. U. 2014 poz. 803.

10 Konferencja Episkopatu Polski, Podstawa programowa katechezy Kościoła katolickiego $w$ Polsce, Kraków 2001; Komisja Wychowania Katolickiego Konferencji Episkopatu Polski, Program nauczania religii, Kraków 2001; Konferencja Episkopatu Polski, Podstawa programowa katechezy Kościoła katolickiego w Polsce, Kraków 2010; Komisja Wychowania Katolickiego Konferencji Episkopatu Polski, Program nauczania religii rzymskokatolickiej w przedszkolach i szkołach, Kraków 2010.

11 See R. Chałupniak, Malarstwo religijne w podręcznikach szkolnych, Opole 2014, p. 37-164. 
for religious and art education the masterpieces of world and Polish painting, of recognized and indisputable aesthetic value, can be found.

Among painting representations used in school textbooks the most frequent were the references to: the Creation of Adam by Michelangelo (31 times), the Return of the Prodigal Son by Rembrandt (24 times and independently, on this subject appear also the reproductions of paintings by Bartolomé Esteban Murillo, Guercino, and Massari), Jesus the Merciful (Jesus, I trust in You - in the versions both by Eugeniusz Kazimirowski and Adolf Hyła - in tolal 23 times), the Last Supper by Leonardo da Vinci (21 times), the Holy Trinity by Andrei Rublev (15 times), the Last Judgment by Hans Memling (14 times), the Conversion of St Paul by Caravaggio (11 times), the Sistine Madonna by Raphael (10 times), the Cathedral in Rouen by Monet (10 times). Several times, different authors placed the reproduction of the icon of the Czestochowa Mother of God and the San Damiano Cross.

Religious paintings were used in different textbooks for a total of 2289 times (including 365 times in case of books for art education). Almost 1400 reproductions were referred to, including those described (with author and title) -795 . That is a numerous amount, but it is worth remembering that this number is divided into many books. If students had the possibility to use different textbooks, they could see many various valuable works of art. Still, it could happen that throughout several years of their education they have encounter only a few religious paintings.

Except for the statement that religious paintings are present in both art and the Catholic religion textbooks, attention has to be paid to the way they are used. From the formal point of view about 600 reproductions i.e. in case of almost half, the descriptions were not complete. Some editors or authors left them out totally or partially, incomplete descriptions appeared (e.g. without the author's data), sometimes names, surnames, or titles were written incorrectly, the same works were titled differently, not always the date of origin was given, and the place where a painting can be found was indicated very rarely.

Among the factors that influence the little use of paintings in the process of education and development are the small dimensions of many reproductions, as well as their poor technical quality. Sometimes paintings were "divided" into two pages thus hiding the middle part of a painting (e.g. Christ's face) and strongly deforming the total reception.

Though religious paintings quite often appeared in textbooks for students, their use was not always methodologically perfected in materials for teachers, 
both of art and religious education. Some editors and authors of textbooks avoided the clear correlation between the subjects and did not suggest how a particular painting can be referred to religious and art contents. From time to time, this was connected to the fear that precise explanations, especially by art education teachers, would influence students' beliefs. At times it was easier to be satisfied just with exposing aesthetical questions and not to refer to the contents presented by paintings.

Analyzing the use of religious paintings in textbooks for art and Catholic Religious Education from the substantive point of view, attention may be paid to great diversification of that question. In textbooks for art education and knowledge about art, religious works, including paintings, were used as examples of innovative solutions in the history of art or of using particular techniques by different artists. The authors of the books for art education, referring to painting masterpieces, often presented very complex issues concerning their formal side. From time to time some explanations connected with the contents of paintings appeared. In some textbooks religious paintings occurred repeatedly and in other ones, referring to this kind of painting was scarce.

The diversification in the use of religious paintings also concerns the textbooks for the Catholic religion lessons. One can point certain books for religion in which references to art, especially paintings, were rather marginal. Religious paintings were drawn away, omitted, and dominated by photos or pictures. They did not play a significant role in the catechetical message. Missing or incomplete descriptions of the reproductions did not allow many students to refer to their art knowledge, associating surnames of artists or specific works of art. Religious and aesthetical knowledge did not correlate, and thus at the same time did not give the opportunity to better remember, revise, and solidify the information learnt, and did not influence students' faith all the more.

On the other hand, the references to religious painting have become indeed obligatory for many editors and authors of textbooks for religion lessons. The chosen paintings most often harmonized with the contents of particular didactic units thus becoming not only an interesting and "nice" illustration but also a significant strengthening of the catechetical message. Religious paintings created the opportunity to visualize catechetical information, go deeper in reflection, and relate it to life. Most frequently, taking up biblical and hagiographic questions, the paintings were unusual "making the moment last forever" and specific depiction of certain people or events, but also the testimonies of faith of the people who contributed to their creation. 
Paintings, in the catechetical message, are included in the widely formulated integral education understood as the development of different human abilities: intellectual, emotional, volitional, or acting. They teach how to discover beauty, be sensitive to its various manifestations, maintain and share it. Shaping aesthetic sensitivity they open the whole profundity of contents that they show explicitly or cover implicitly. They instil respect for reality, which exceeds even the most genius depictions. They also unveil the mysteries of what is visible and made visible, and yet is "as if beyond the veil" demanding to be discovered, known, accepted, and experienced.

In newer textbooks for the Catholic religion, published after 2010, one can notice a positive trend to more frequent references to various works of art, including painting depictions. The use of the richness brought about by the whole heritage of art is connected to the opportunity to correlate the impact of teachers of religion and art education. Mutual learning, referring, and deepening the contents which are programmed for the two subjects can benefit a greater knowledge, develop better skills, and help mature attitudes of students themselves.

\section{Conclusion}

Contemporary culture - as already noted - is becoming more and more visual. Thus, contemporary catechesis, referring to its rich, centuries-long experience, should often use different types of images.

The article forms a part of a wider project whose task is to present how religious paintings can be used in contemporary catechesis. The research field is wide and includes questions related to both religious education and widely understood aesthetic education.

Using images in education is not only the achievement of specific objectives in catechesis, but also gives an opportunity to creatively engage students and shape their aesthetic sensibility. Working with the image creates the possibility of discovering the beauty, to see it in reality and "keeping the heart", that is the enrichment of the beauty of one's humanity.

The second part of the text presented the necessity of a correlation between religious and art education: how religious painting is used in school textbooks. Still, detailed juxtaposition of works of art, used in various textbooks, and the analysis that has been made enable to make significant conclusions and to 
propose what works of art are worth introducing into contemporary catechesis. Generally, in school education, different kinds of paintings referring directly or indirectly to religious questions are used. They appear both in textbooks intended for general art education, and in religion textbooks. The authors of these publications have different attitudes towards these paintings. In the art education textbooks they are predominantly presented as specific examples of certain painting techniques dominating in particular epochs. The issue of the content, showing the message brought by the paintings, is rarely raised. Browsing these books one can sometimes have an impression that their authors refer to Christianity at some distance, avoiding clear references to contents presented in religious paintings. Religion textbooks, in turn, which in Polish schools constitute a specific form of catechesis, clearly show paintings in their illustrative function. Depending on the attitudes of the authors, paintings are used as an example or representation of certain religious contents.

\section{Bibliography}

Aranci G., L'uso delle immagini in alcuni momenti della storia della catechesi, Firenze 2001. Chałupniak R., Arcydzieła malarstwa w katechezie, Opole 2013.

Chałupniak R., Malarstwo religijne w podręcznikach szkolnych, Opole 2014.

Faith and Beauty. A Theological Aesthetic, ed. E. Farley, Ashgate 2001.

Kawecki W., Teologia piękna. Poszukiwanie locus theologicus w kulturze współczesnej, Poznań 2013.

Lange G., Bilder zum Glauben, München 2002.

Popiołek-Rodzińska I., Wychowanie plastyczne w przedszkolu, in: E. Osewska, J. Stala (eds.), Wychowanie dzieci w wieku przedszkolnym, Tarnów 2005, p. 113-126.

Popiołek-Rodzińska I., Zamirska E., Wychowanie przez sztuke w klasach I-VI, in: J. Stala (ed.), Wychowanie dzieci w młodszym wieku szkolnym. Część I. Wychowanie ogólne, Tarnów 2006, p. 89-110.

Tomasik P., Religia $w$ dialogu z edukacja, Warszawa 2004.

Zellma A., Nowa formuła korelacji w edukacji szkolnej i jej realizacja w nauczaniu religii, "Katecheta" 55 (2011), nr 5, p. 5-16. 